\title{
COVID 19-Induced Lockdown 2.0 and Looming Crisis across Sectors of Economy: Evidence from the Indian States
}

Tiken Das $^{\dagger *}$ and Pradyut Guha*

\section{Abstract}

Due to the coronavirus-induced lockdown, most economic activities have come to a standstill. It assumes that lockdown with social distancing measures may lower the spread of infected cases, as it will be over-optimistic to expect the complete burnout of the virus. The present study attempts to access the loss of the country's economy in the wake of the coronavirus-induced 50-day lockdown (40-day lockdown + 10-day preoperative period). The data on Net State Value Added (NSVA) at base price 2011-2012 by economic activity was collected from the Reserve Bank of India for five consecutive financial years. This study assumes 10-day for restoring back to the production capacity, although each sector has its own dynamics and different cycles. The autoregressive process was used for forecasting the growth rate of Gross Value Added. The study found that across Indian states, the amount of loss was most extensive in the state of Maharashtra, as against Tamil Nadu and Karnataka. Besides the manufacturing sector, the enormous burden of loss was reflected in the real estate sector, followed by ownership of dwellings and professional services. The highest per capita loss of the NSVA was found in the state of Goa, as against Delhi. The study argued that all the affected sectors likely to register negative growth in the subsequent two quarters.

Keywords: COVID- 19; Lockdown 2.0; Economic Loss; Net State Value Added; Per Capita Loss; India

\footnotetext{
${ }^{\dagger}$ Assistant Professor, Department of Economics, Nowgong College, AT Rd, Christianpatty, Nagaon, Assam,782001 ${ }^{*}$ Corresponding Author, Email: tikenhyd@gmail.com

${ }^{¥}$ Assistant Professor, Department of Economics, Sikkim University, 6th mile, Samdur, P. O.: Tadong-737102 Gangtok, Sikkim, Email: pguha@cus.ac.in

(C) 2020 Das \& Guha. This is an Open Access article distributed under the terms of the Creative Commons Attribution License (http://creativecommons.org/licenses/by/2.0), which permits unrestricted use, distribution, and reproduction in any medium, provided the original work is properly cited.
} 


\section{Introduction}

Coronaviruses are a family of the viruses that can cause illnesses such as the common cold, severe acute respiratory syndrome and middle east respiratory syndrome (Coronavirus Disease 2019, 2020). In 2019, a new coronavirus (COVID19) was identified as the cause of a disease outbreak that originated in the Wuhan city of China in December 2019, and the virus is now known as the severe acute respiratory syndrome coronavirus 2 (Coronavirus Disease 2019, 2020). The common symptoms of this COVID- 19 pandemic include fever, cough, shortness of breath or difficulty in breathing, chills, and repeated shaking with chills (Centers for Disease Control and Prevention, 2020; World Health Organization, 2020). The genesis of symptom appears typically around five days from the time of exposure, but sometimes can be detected within 2-14 days after exposure to the virus (Velavan and Meyer, 2020). As of 11 May 2020, more than 4.11 million cases have been reported across 187 countries and territories, resulting in more than 2,82,000 deaths (Center for Systems Science and Engineering, 2020). And in India, by this date (that is, 11 May 2020), the Ministry of Health and Family Welfare has confirmed a total of 67,152 COVID-19 cases, out of which 20,917 recovered but 2,206 persons faced death. However, in India, the infection rate of COVID-19 is considerably lower (1.7) than the worst affected countries of the world (Sinha, 2020).

On 24 March, the Prime Minister of India Narendra Modi has declared a nationwide lockdown for 21- day (phase I: 25 March 2020 14 April 2020), which further extended by 19 day (phase II: 15 April 2020 - 3 May 2020). While it will be too optimistic to expect a complete burnout of the virus, the lockdown coupled with social distancing measures, is expected to lower the number of the infected persons (Srivastava, 2020). It is obvious that due to the coronavirusinduced lockdown, most economic activities have come to a standstill. The Reserve Bank of
India (RBI) is of the view that the COVID-19 outbreak and the prolonged lockdown is likely to bring a devastating impact on the overall economy (including the rural). Indian economy is expected to lose nearly $\$ 100$ billion during the 21- day lockdown and the export sector could lose nearly 15 million jobs (Coronavirus: India's Export Sector, 2020). It is expected that the service sectors like transport, hotel and restaurant, and real estate activities which account for around $22 \%$ in the Gross Value Added (GVA) will lose $50 \%$ of their output in the first quarter (Q1) of Financial Year (FY) 2021 (Srinivasan, 2020). The lockdown has also triggered a massive exodus of reverse migration of labours and waged workers from the cities to their native villages (Kidangoor, 2020). The ban on citizen's stepping out of their residence in the wake of this pandemic has brought up tremendous challenges for India's retail sector, which is largely reliant on consumers' confidence (Sanghera, 2020). Despite the contribution of $12 \%$ to India's GDP, 38 million workers lost their job in the aviation and tourism industries, which is $70 \%$ of their total workforce (Sanghera, 2020).

Moreover, the subsequent lockdown in the country has brought down the aggregate demand considerably (Unnikrishnan, 2020). The government has announced several slew measures like the direct cash transfer to farmers, hiking wages under the Mahatma Gandhi National Guarantee Act (MGNREGA), scheme, ${ }^{1}$ and the utilisation of welfare funds for construction workers to offset the adverse impact on rural demand. Moreover, the RBI has cut the repo rate to $4.4 \%$, the lowest in 15 years. The cash reserve ratio for all banks has been reduced by 100 basis points to release INR 1.37 lakh crore across the banking system. Within these contexts, the present study attempts to access the loss of the country's economy due to the coronavirus-induced 50-day lockdown (40day lockdown + 10-day preoperative period). Moreover, an attempt has also made to forecast

\footnotetext{
${ }^{1}$ A flagship scheme launched by the Government of India in 2006 guaranteeing at least 100 days of paid work in a year (How the NDA, 2019)
} 
the real GVA growth rate for the subsequent two quarters (for Q4 of 2019-20 and Q1 of 2020-21). A number of studies (e.g. Fernandes, 2020; Kumar et al., 2020; Sengupta and Jha, 2020; Gopinath, 2020) have attempted to assess the economic condition of the country following the coronavirus-induced lockdown. However, there are limited studies which evaluate the possible adverse effect of the extended period of lockdown on manufacturing and service sectors across Indian states. This is probably the first empirical study to forecast the growth rate of real GVA across sectors of the Indian economy by covering the phases of full lockdown, partial lockdown and period of unlocking until June 2020.

The rest of the paper is organised as follows. The data and methodology are covered in the second section. The third section describes the results and discussion of the study. Conclusions are covered in the final section of the paper.

\section{Data and Methodology}

The study was based on secondary data, collected from the RBI's database on Indian Economy and Census of India 2011. The data on Net State Value Added (NSVA) at base price 2011-2012 by economic activity was collected for five financial years (2014-2015, 2015-2016, 2016-2017, 2017-2018 and 2018-2019). NSVA is defined as the Net State Domestic Product (NSDP) plus subsidies on product minus taxes on the product. The NSVA is generally a better measure of total economic output and growth of a state. While each sector has its own dynamics and different cycles, the present study assumes 10-day to migrate to the production capacity. Thus, the study evaluated the cost of the economy for 50- day (40- day lockdown +10 - day preoperative period). After calculating the average of the five years NSVA across states and economic activities, the study estimated the value of the NSVA per day. While estimating the economic loss of 50- day lockdown, the present study included seven sectors - mining and quarrying; manufacturing; construction; trade, repair, hotels and restaurants; transport, storage, communication \& services related to broadcasting; financial services; real estate, ownership of dwelling \& professional services, which were complete shutdown or nearcomplete shutdown. No concrete estimates for agriculture, forestry and fishing can be made at the moment, because agriculture being seasonal in nature cannot be ascertained exactly (Bhasin, 2020; Mishra, 2020). Besides, electricity, gas, water supply and other utilities; and public administration, defence and other services have continued as earlier, so they may not witness any loss of economic activity (Mishra, 2020). It is assumed that a few functional sub-sectors may have a nullifying effect on the disruptions in excluded sectors like agriculture, public administration which cannot be quantified accurately (Mishra, 2020). Moreover, to forecast the growth rate of GVA (for Q4 of 2020 and Q1 of 2021), the present study used GVA data of 2019-2020 across quarters and economic activities. Considering an autoregressive process of order $p[A R(p)]$, the forecasting is done with the assumption that the absolute values of slope coefficients are less than unity (Johnston and Dinardo, 1997). The econometric formulation of $\operatorname{AR}(p)$ can be specified as $Y_{t}=\Omega_{j} Y_{t-j}+u_{t}$ with $\left|\Omega_{j}\right|$ $<1$, where $\mathrm{j}=1,2, \ldots . . \mathrm{p} ; \mathrm{t}=\mathrm{Q} 4$ of 2019-20, Q1 of 2020-21; $Y$ represents GVA in any particular sector (mining \& quarrying; manufacturing; construction; trade, hotels, transport, communication and services related to broadcasting; financial, real estate \& professional services); $\Omega$ represents the slope coefficient and $u$ is the white noise error term. After obtaining the forecasted figures of GVA across sectors and states, the quarter to quarter growth rate was calculated for Q4 of 2019-20 and Q1 of 2020-21.

\section{Results and Discussion}

The analysis of the data at the disaggregated level reveals that the amount of loss in mining and quarrying (M\&Q) sector is largest in Maharashtra with INR 74.54 billion, followed by Rajasthan and Gujarat with INR 63.05 billion and INR 39.11 billion, respectively (Table 1). However, the amount of loss in this sector is relatively minimal in Chandigarh, Sikkim and Mizoram for their limited concentration of such activities. As an important sector of the 
economy, the amount of loss in the manufacturing sector is largest in Maharashtra with INR 459.95 billion, as against INR 346.61 billion and INR 275.74 billion for Gujarat and Tamil Nadu, respectively. The loss in the manufacturing sector is low in Andaman and Nicobar, Mizoram and Nagaland during these lockdown phases. Regarding the loss in the construction works, the amount of loss is largest in Tamil Nadu with INR 168.11 billion, followed by Uttar Pradesh and Maharashtra with a loss of INR 156.92 billion and INR 139.15 billion, respectively. The state of Andaman, Sikkim and Chandigarh also incur minimal losses in the construction works during this 50- day lockdown.

Further, the loss in the service sectors like trade, repair, hotels and restaurants is highest in Maharashtra with INR 221.82 billion, as against Tamil Nadu and West Bengal with INR 184.39 billion and INR 167.57 billion, respectively. However, the loss on these service sectors is seen to be lowest in Andaman Nicobar Island, Arunachal Pradesh and Sikkim. Another form of service sectors like transport, storage, communication and services related to broadcasting has registered highest losses in Maharashtra with INR 124.53 billion, as against Uttar Pradesh and Delhi.

The amount of loss in such service sectors is relatively low in the North Eastern States (NES), notably Arunachal Pradesh, Sikkim and Mizoram. Maharashtra registers the highest loss in the financial services with INR 246.29 billion. The states, like Mizoram, Arunachal Pradesh and Andaman Nicobar Island incur the least loss in the financial sector. The service sectors like real estate, ownership of dwellings and professional services are expected to bring colossal loss for Karnataka with INR 440.94 billion, as against Maharashtra and Tamil Nadu with INR 393.91 billion and INR 252.22 billion, respectively. However, the NES like Mizoram, Arunachal
Pradesh and Andaman Nicobar Island incurs the least loss in such services. It can be observed that the aggregate loss is highest in Maharashtra with INR 1,660.19 billion, followed by Tamil Nadu and Karnataka with INR 1,065.55 billion and INR $1,024.72$ billion, respectively. The total loss is recorded to be minimal in Mizoram, Arunachal Pradesh and Andaman Nicobar Island. It can also be observed that the Indian economy is expected to lose around INR 10,895.68 billion during this 50- day nationwide lockdown (Table 1). Moreover, the sector, that is hugely impacted is manufacturing (loss of INR 2,519.48 billion), as against real estate, ownership of dwellings and professional services (loss of INR 2,443.39 billion). As Figure 1 shows, among the manufacturing components, the largest share of the loss $(40 \%)$ is on other manufactured goods (chemicals, mineral products, non-metallic, plastics \& rubbers, pulp \& paper, transport equipment, wood products etc.), as against $22 \%$ in the machinery and equipment.

Figure 2 depicts that the highest per capita loss of NSVA is reported in Goa, followed by Delhi. Moreover, the significant loss of per capita NSVA is observed in the states of Chandigarh, Sikkim, Puducherry, Uttarakhand and Gujarat, while it is INR 56,339 in India, as a whole. The contribution of Goa and Puducherry on the total loss of the economy is only INR 46.86 billion (0.4\%) and INR 23.53 billion (0.2\%), respectively, which can be possible because of their smaller size of the economy. However, their rank on per capita loss of NSVA is first and fifth, respectively, and this reflects the greater dependence on the manufacturing sector. It is clear from Figure 2 that the larger states like Uttar Pradesh, Bihar, Madhya Pradesh and West Bengal has reported much lower value on per capita loss of the NSVA in 50- day lockdown in India. Except for the state of Sikkim, the per capita loss of NSVA is relatively lower for the remaining NES (Figure 2). 


\begin{tabular}{|c|c|c|c|c|c|c|c|c|}
\hline State/UT & $M \& Q$ & M & C & TRH\&R & TSC\&B & FS & REOPS & Total Loss \\
\hline Andhra Pradesh & 21.39 & 66.4 & 61.63 & 64.22 & 69.88 & 28.63 & 63.63 & 375.78 \\
\hline Arunachal Pradesh & 0.5 & 0.73 & 2.48 & 1.04 & 0.52 & 0.41 & 0.61 & 6.29 \\
\hline Assam & 26.21 & 28.82 & 21.72 & 40.61 & 14.34 & 8.15 & 15.61 & 155.46 \\
\hline Bihar & 3.07 & 34.72 & 43.22 & 102.52 & 41.71 & 17.75 & 46.45 & 289.44 \\
\hline Chhattisgarh & 26.66 & 45.77 & 37.2 & 20.95 & 12.26 & 12.65 & 33.83 & 189.32 \\
\hline Goa & 0.72 & 28.8 & 2.37 & 4.54 & 2.01 & 3.32 & 5.1 & 46.86 \\
\hline Gujarat & 39.11 & 346.61 & 72.29 & 140.87 & 55.9 & 66.82 & 62.67 & 784.27 \\
\hline Haryana & 0.65 & 98.6 & 50.88 & 72.26 & 33.18 & 24.61 & 95 & 375.18 \\
\hline Himachal Pradesh & 0.42 & 39.85 & 10.96 & 8.58 & 6.22 & 6.25 & 14.71 & 86.99 \\
\hline Jammu \& Kashmir & 0.7 & 11.3 & 11.41 & 12.43 & 7.49 & 5.82 & 14.27 & 63.42 \\
\hline Jharkhand & 22.29 & 43.54 & 22.97 & 31.75 & 18.96 & 8.61 & 22.54 & 170.66 \\
\hline Karnataka & 9.56 & 188.07 & 82.91 & 154.02 & 77.57 & 71.65 & 440.94 & 1024.72 \\
\hline Kerala & 4.61 & 58.95 & 92.05 & 123.13 & 49.55 & 29.3 & 92.66 & 450.25 \\
\hline Madhya Pradesh & 27.77 & 59.43 & 60.66 & 81.65 & 41.58 & 29.73 & 35.74 & 336.56 \\
\hline Maharashtra & 74.54 & 459.95 & 139.15 & 221.82 & 124.53 & 246.29 & 393.91 & 1660.19 \\
\hline Manipur & & 0.66 & 2.54 & 3.29 & 1.5 & 0.49 & 1.86 & 10.34 \\
\hline Meghalaya & 1.76 & 2.47 & 2.28 & 6.31 & 1.66 & 0.98 & 1.73 & 17.19 \\
\hline Mizoram & 0.12 & 0.12 & 1.85 & 1.78 & 0.62 & 0.39 & 0.61 & 5.49 \\
\hline Nagaland & 0.16 & 0.29 & 2.02 & 2.26 & 1.04 & 0.73 & 1.72 & 8.22 \\
\hline Odisha & 33.01 & 55.05 & 32.58 & 45.14 & 27.29 & 17.49 & 30.76 & 241.32 \\
\hline Punjab & 0.9 & 63.33 & 31.17 & 52.12 & 22.87 & 25.58 & 41.21 & 237.18 \\
\hline Rajasthan & 63.05 & 91.74 & 79.42 & 109.45 & 49.69 & 28.95 & 95.82 & 518.12 \\
\hline Sikkim & 0.02 & 9.4 & 1.26 & 1.07 & 0.58 & 0.51 & 0.7 & 13.54 \\
\hline Tamil Nadu & 6.01 & 275.74 & 168.11 & 184.39 & 94.29 & 84.79 & 252.22 & 1065.55 \\
\hline Telangana & 23.39 & 95.01 & 38.39 & 122.34 & 50.63 & 49.21 & 154.07 & 533.04 \\
\hline Tripura & 4.97 & 1.72 & 2.56 & 4.36 & 1.46 & 1.65 & 2.31 & 19.03 \\
\hline Uttarakhand & 3.05 & 81.16 & 17.37 & 28.35 & 13.8 & 5.98 & 9.36 & 159.07 \\
\hline Uttar Pradesh & 17.17 & 170.65 & 156.92 & 141.9 & 104.21 & 55.53 & 198.57 & 844.95 \\
\hline West Bengal & 9.65 & 109.49 & 76.5 & 167.57 & 60.93 & 54.03 & 121.94 & 600.11 \\
\hline Andaman \& Nicobar & 0.12 & 0.07 & 0.98 & 0.72 & 0.8 & 0.22 & 0.59 & 3.5 \\
\hline Chandigarh & 0.003 & 1.31 & 1.75 & 12.5 & 1.81 & 5.02 & 5.71 & 28.103 \\
\hline Delhi & 9.8 & 40.28 & 30.99 & 87.87 & 94.41 & 105.72 & 182.94 & 552.01 \\
\hline Puducherry & 0.49 & 9.45 & 4.52 & 3.08 & 1.18 & 1.21 & 3.6 & 23.53 \\
\hline Grand Total & 431.873 & 2519.48 & 1363.11 & 2054.89 & 1084.47 & 998.47 & 2443.39 & 10895.68 \\
\hline \multicolumn{9}{|c|}{$\begin{array}{l}\text { Source: Author's estimation based on the NSVA data collected from the RBI for five years: 2014-2015, 2015- } \\
\text { 2016, 2016-2017, 2017-2018 and 2018-2019 } \\
\text { Note: M\&Q= Mining and Quarrying; M= Manufacturing; C= Construction; TRH\&R= Trade, Repair, Hotels and } \\
\text { Restaurants; TSC\&B= Transport, Storage, Communication \& Services related to Broadcasting; FS= Financial } \\
\text { Services; REOPS= Real Estate, Ownership of Dwelling \& Professional Services }\end{array}$} \\
\hline
\end{tabular}




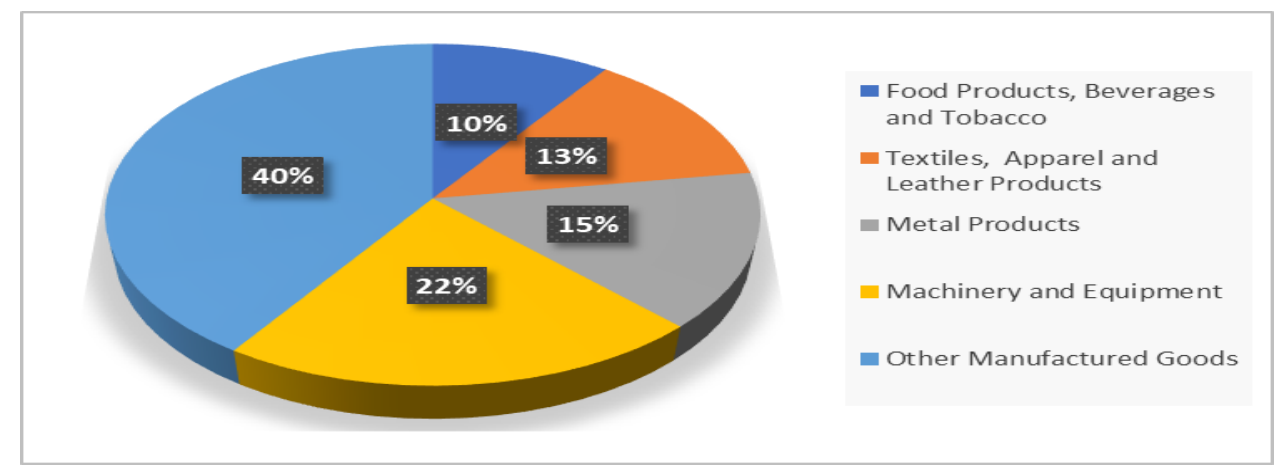

Figure 1: Share of Different Components in Total Loss to Manufacturing Sector on 50- Day Lockdown (40- day + 10- day) in India

Source: Author's estimation based on the Gross Value-Added data collected from the RBI for five years: 2014-2015, 2015-2016, 2016-2017, 2017-2018 and 2018-2019

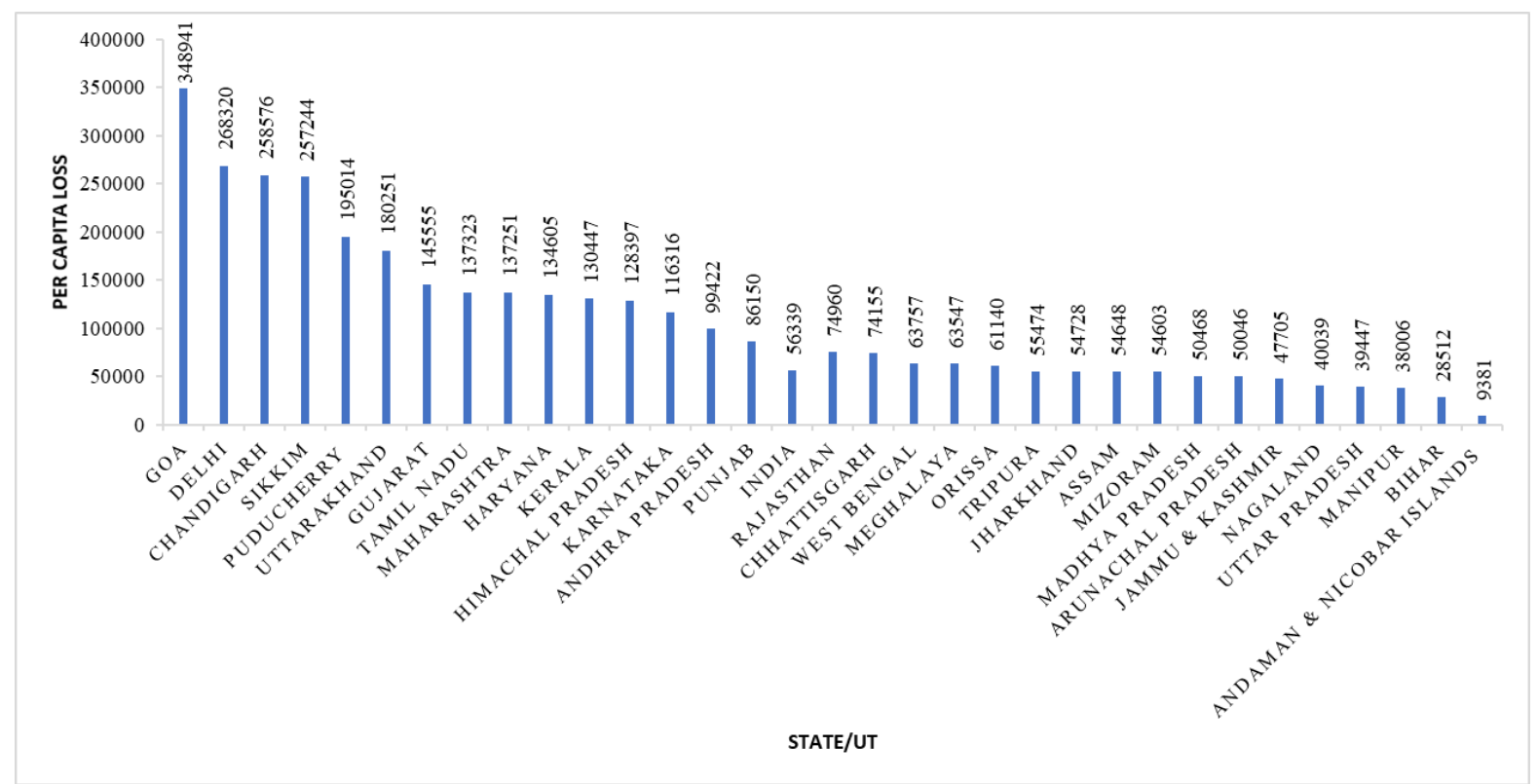

Figure 2: Per Capita Loss of NSVA across States and Union Territories in 50- Day Lockdown (40- day + 10- day) in India (Amount in INR)

Source: Author's estimation based on the NSVA data collected from the RBI for five years: 2014-2015, 2015-2016, 2016-2017, 2017-2018 and 2018-2019; Census of India, 2011

As Figure 3 shows, the phase of 50- day lockdown likely to pull down the growth rate of the economy drastically across sectors. It can also be observed that the GVA at basic price shows a negative growth rate for both the final quarter of 2019-20 and the first quarter of 202021.
Similarly, sectors like $M \& Q$, construction, THTCS, FRPS may register negative growth in both the quarters. However, the manufacturing sector maintains a negative growth rate in both the pre and post lockdown phases. 

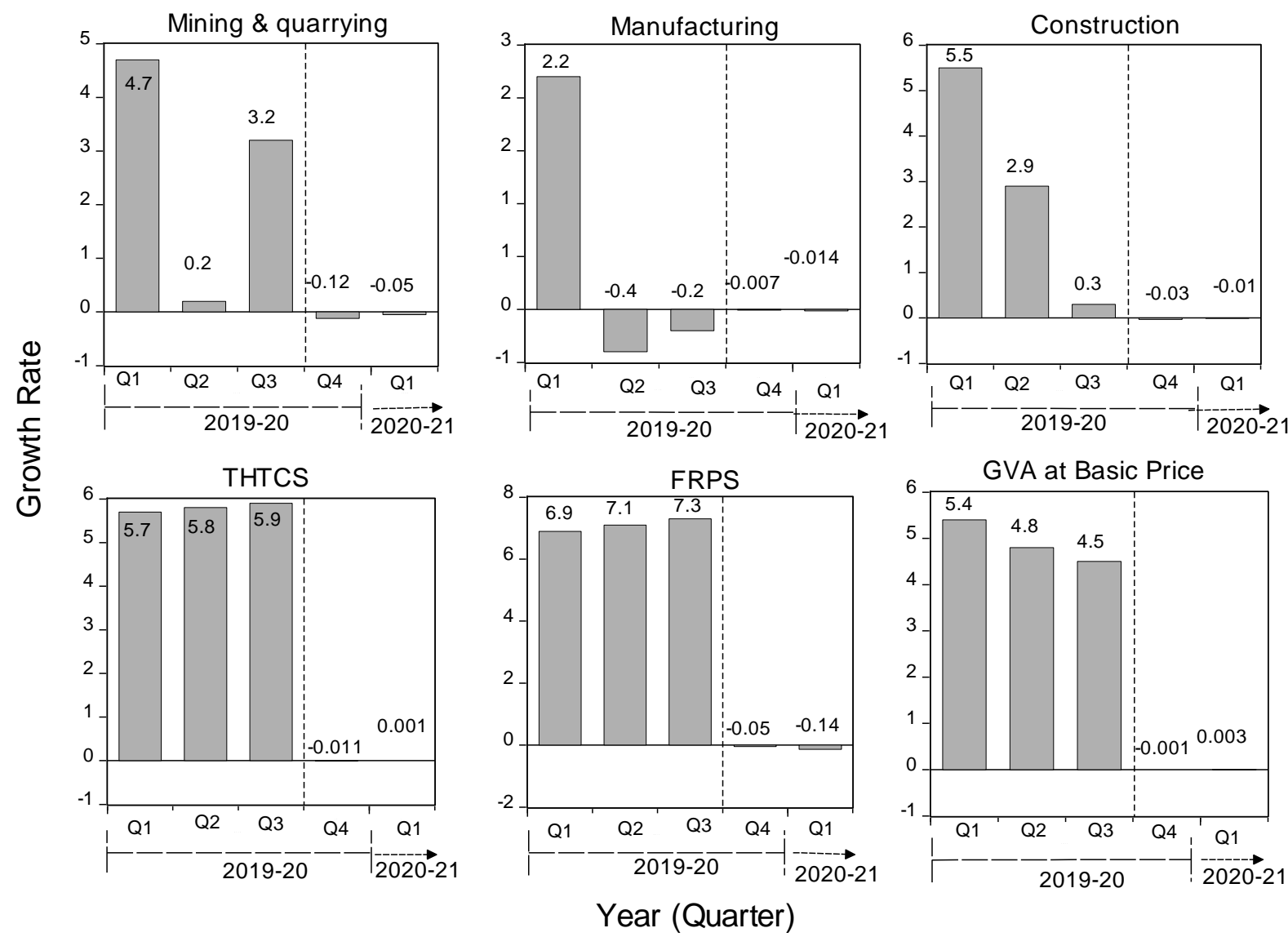

FRPS indicates Financial, Real State \& Professional Services

THTCS indicates Trade, Hotel, Transport, Communication and Services related broadcasting

Figure 3: Forecasted Growth Rate across Sectors affected by Lockdown in India Source: Authors' estimation based on GVA data compiled from RBI for 2019-2020

\section{Conclusion}

It is obvious that due to the coronavirus-induced lockdown, most economic activities have come to a standstill in India. The present study was conducted to access the loss of the economy in the wake of the coronavirus-induced 50- day lockdown. Moreover, an attempt was also made to forecast the real GVA growth rate for the subsequent two quarters (for Q4 of 2019-20 and Q1 of 2020-21). The study found that across Indian states, the amount of loss was largest in Maharashtra, as against Tamil Nadu and Karnataka. The total loss was minimal in Mizoram, Arunachal Pradesh and Andaman Nicobar Island. Besides the manufacturing sector, the massive burden of loss was reflected in real estate, ownership of dwellings and professional services. The highest per capita loss of NSVA was reported in Goa, as against Delhi. The significant loss of the per capita NSVA was also observed in the states of Chandigarh,
Sikkim, Puducherry, Uttarakhand and Gujarat. The larger states like Uttar Pradesh, Bihar, Madhya Pradesh and West Bengal reported much lower value on per capita loss of the NSVA in 50- day lockdown in India. Except for the state of Sikkim, the per capita loss of NSVA was relatively low for the remaining NES. It was observed that all the affected sectors likely to register negative growth in the subsequent two quarters. It is worth noting that in an economy already reeling under a demand depression, rising unemployment, and lowering of industrial output and profits; what could be the magnitude of the impact of a complete social and economic shutdown may not be easy to estimate, but it is likely to be far more severe.

\section{References}

Bhasin K. (2020). Govt can cushion economic impact of the lockdown. Retrieved on 25 March from,

https://www.livemint.com/news/india/govt- 
can-cushion-economic-impact-of-the-lockdown11585157317394.html

Center for Systems Science and Engineering. (2020). Coronavirus COVID-19 global cases by the Center for Systems Science and Engineering at Johns Hopkins University. Retrieved on 15 April from, https://gisanddata.maps.arcgis.com/apps/opsd ashboard/index.html\#/bda7594740fd40299423 467b48e9ecf6

Centers for Disease Control and Prevention. (2020). Symptoms of Coronavirus. Retrieved on 13 May from, https://www.cdc.gov/coronavirus/2019ncov/symptoms-testing/symptoms.html

Coronavirus disease 2019 (COVID-19). (2020, March 30). Retrieved on 30 March from, https://www.mayoclinic.org/diseasesconditions/coronavirus/symptoms-causes/syc20479963

Coronavirus: India's export sector may lose 15 million jobs due to lockdown. (2020, April 11). Business Today. Retrieved on 11 April from, https://www.businesstoday.in/current/econom $y$-politics/coronavirus-india-export-sector-maylose-15-million-jobs-due-to-

lockdown/story/400736.html

Fernandes, N. (2020). Economic effects of coronavirus outbreak (COVID-19) on the world economy. Retrieved on 14 September from, https://dx.doi.org/10.2139/ssrn.3557504

Gopinath, G. (2020). The great lockdown: the worst economic downturn since the great depression. Retrieved on 14 September from, https://blogs.imf.org/2020/04/14/the-greatlockdown-worst-economic-downturn-since-thegreat-depression/

How the NDA government came to own a UPA flagship scheme. (2019, January 18). The Economic Times. Retrieved on 14 September from,

https://economictimes.indiatimes.com/news/e conomy/agriculture/how-the-nda-governmentcame-to-own-a-upa-flagshipscheme/articleshow/67586203.cms?from $=\mathrm{mdr}$
Johnston. J., Dinardo, J. (1997). Econometric Methods. New York: McGraw-Hill.

Kidangoor A. (2020). Modi's hasty coronavirus lockdown of India leaves many fearful for what comes next. TIME. Retrieved on 31 March from, https://time.com/5812394/india-coronaviruslockdown-modi/

Kumar, A., Padhee, A. K., Kumar, S. (2020). How Indian agriculture should change after COVID-

19. Food Security, 12, 837-840. DOI: 10.1007/s12571-020-01063-6

Mishra H. H. (2020). Coronavirus in India: COVID-19 lockdown may cost the economy Rs 8.76 lakh crore; here's how. Business Today. Retrieved on 28 March from, https://www.businesstoday.in/opinion/column s/coronavirus-in-india-covid-19-india-lockdowneconomy-cost-gdp-gva-nationwideshutdown/story/399477.html

Sanghera, T. (2020). World's biggest virus lockdown saves lives, but hurts businesses. ALJAZEERA. Retrieved on 20 April from, https://www.aljazeera.com/ajimpact/worldbiggest-virus-lockdown-saves-lives-hurtsbusinesses-200417081325170.html

Sengupta, S., Jha, M.K. (2020). Social policy, COVID-19 and impoverished migrants: challenges and prospects in locked down India. The International Journal of Community and Social Development, 2(2), 152-172. DOI: $10.1177 / 2516602620933715$

Sinha A. (2020). One COVID-19 positive infects 1.7 in India, lower than in hot zones. The Indian EXPRESS. Retrieved on 19 March from, https://indianexpress.com/article/coronavirus/ coronavirus-india-infection-rate-china6321154/

Srinivasan, V. (2020). COVID impact: Indian economy loses $\$ 4.64$ billion on each lockdown day. The Federal. Retrieved on 6 April from, https://thefederal.com/analysis/indianeconomy-risks-contraction-due-to-covidlockdown-report/

Srivastava, A. (2020). Coronavirus in India: Why 21-day nation-wide lockdown can help break the virus chain? India Today. Retrieved on 26 
March from,

https://www.indiatoday.in/india/story/coronavi rus-in-india-why-21-day-nation-wide-lockdowncan-help-break-the-virus-chain-1659773-202003-26

Unnikrishnan, D. (2020). Lockdown impact: RBI report confirms prolonged pain for rural economy. Retrieved on 9 April from, https://www.moneycontrol.com/news/busines s/economy/lockdown-impact-rbi-reportconfirms-prolonged-pain-for-rural-economy5127441.html

Velavan, T.P., Meyer, C.G. (2020). The COVID-19 epidemic. Tropical Medicine and International Health, 25 (3), 278-280. DOI:

10.1111/tmi.13383

World Health Organization. (2020). WHO

Director-General's opening remarks at the media briefing on COVID-19-11 March 2020.
Retrieved on 11 March from, https://www.who.int/dg/speeches/detail/whodirector-general-s-opening-remarks-at-themedia-briefing-on-covid-19---11-march-2020

\section{Conflict of Interest}

We declare that we do not have any conflict of interest.

\section{Acknowledgement}

We would like to thank the anonymous reviewers for their suggestions and comments.

\section{Author Contribution}

Conceptualisation: Dr Tiken Das; Methodology: Dr Tiken Das and Dr Pradyut Guha; Statistical Analyses: Dr Tiken Das and Dr Pradyut Guha; Writing-original draft: Dr Tiken Das; WritingReview \& Editing: Dr Tiken Das and Dr Pradyut Guha 